\title{
Hyperglycaemia and hyperinsulinaemia: is insulin-degrading enzyme the missing link?
}

\author{
J. Fawcett • W. C. Duckworth
}

Received: 23 April 2009 /Accepted: 12 May 2009/Published online: 6 June 2009

(C) Springer-Verlag 2009

Keywords Hyperglycaemia · Insulin action · Insulin degradation · Insulin-degrading enzyme $\cdot$ Protein metabolism

\section{Abbreviations \\ GK Goto-Kakizaki \\ IDE Insulin-degrading enzyme}

The complex metabolic disturbances seen in diabetes are not just related to alterations in glucose homeostasis, but also include changes in fat and protein metabolism. Each change cannot be considered in isolation, since changes in one of these factors will lead to alterations in another. In the insulin-resistant state, glucose levels increase and there is also relative hyperinsulinaemia, which is exacerbated by a reduction in insulin degradation under these conditions. The process of insulin metabolism starts with

J. Fawcett $(\bowtie)$

Research Service, Phoenix VA Health Care System, 650 E. Indian School Road,

Phoenix, AZ 85012, USA

e-mail: janet.fawcett@va.gov

W. C. Duckworth

Endocrinology, Phoenix VA Health Care System,

Phoenix, AZ, USA

W. C. Duckworth

School of Life Sciences, Arizona State University,

Tempe, AZ, USA

W. C. Duckworth

Department of Medicine, University of Arizona,

Phoenix Campus,

Phoenix, AZ, USA binding of insulin to its receptor on the cell surface. The insulin receptor is then internalised into endosomes and degradation begins [1]. Insulin degradation occurs by the action of insulin-degrading enzyme (IDE) [2], which is responsible for the majority of cellular insulin metabolism (reviewed in [1]). Although the majority of IDE is cytosolic, it is also found in endosomes, peroxisomes and mitochondria [3-5]. It is present in all cell types, not just those responsive to insulin, and in all organisms, from yeast to mammals $[1,6]$, suggesting that IDE has functions in addition to its degradative one. There is increasing evidence of a regulatory role for IDE in a variety of cell functions. Some of these include regulation of the proteasome [7-9], androgen and glucocorticoid receptors [10], peroxisome [3], myoblast differentiation [11], lymphocyte antigen presentation [12] and yeast bud site selection [13].

Insulin metabolism is altered in patients with type 2 diabetes, and human genetic studies have linked polymorphisms in the gene encoding IDE to an increased risk of type 2 diabetes [14] and of Alzheimer's disease [15, 16]. Knockdown of Ide in mice causes insulin resistance and hyperglycaemia, and plaques similar to those seen in Alzheimer's disease are also found [17]. The GotoKakizaki (GK) rat has a mutation in IDE that causes altered cellular insulin degradation [18] in addition to other characteristics typical of type 2 diabetes.

Despite the obvious importance of IDE in the control of insulin metabolism and other metabolic processes, the metabolic control of IDE has not been extensively studied. It has been shown that certain NEFA inhibit IDE [19] and that other small molecules may interact with and inhibit IDE activity [20, 21]. But more information on the control of IDE is needed. 
In this issue of Diabetologia, Pivovarova et al. [22] present the results of a study of the effects of glucose and insulin exposure on the activity and levels of IDE. They show that insulin increases the activity of IDE in extracts of cells that have been treated for $24 \mathrm{~h}$ with $10 \mathrm{~mol} / 1 \mathrm{l}$ of insulin. If the glucose concentration is increased from $1 \mathrm{~g} / 1(5.55 \mathrm{mmol} / \mathrm{l}$; 'normal' glucose) to $4.5 \mathrm{~g} / \mathrm{l}$ ( $25 \mathrm{mmol} / \mathrm{l}$; 'high' glucose), the increase in IDE activity promoted by insulin is abolished. This suggests that the reduction in insulin metabolism seen in cases of type 2 diabetes may be due to an effect of hyperglycaemia. How this insulin-induced increase in IDE activity occurs is unknown. The authors measured both mRNA and protein levels, and neither were altered by insulin under conditions of normal glucose concentrations. These findings suggest a change in the kinetic properties of the enzyme, such as the $K_{\mathrm{m}}$ or $V_{\max }$, which could be measured in future experiments in enzyme preparations isolated from cells treated with glucose and/or insulin. Increasing the glucose levels per se did not change the expression of IDE mRNA. The addition of insulin to the high-glucose conditions increased levels of $I D E$ mRNA by approximately $30 \%$ relative to the levels in the non-insulin-treated cells under high-glucose conditions. Since neither the levels nor the activity of the protein are altered, this difference does not appear to be biologically significant.

It has been shown that alternative splicing of IDE premRNA can produce an inactive form of the enzyme [23]. Pivovarova et al. [22] show that glucose levels do not affect the levels of either the $15 \mathrm{a}$ (active) or $15 \mathrm{~b}$ (inactive) splice variants. However, insulin treatment of cells in the presence of either normal or high glucose levels increases the expression of the 15a splice variant; levels of the inactive

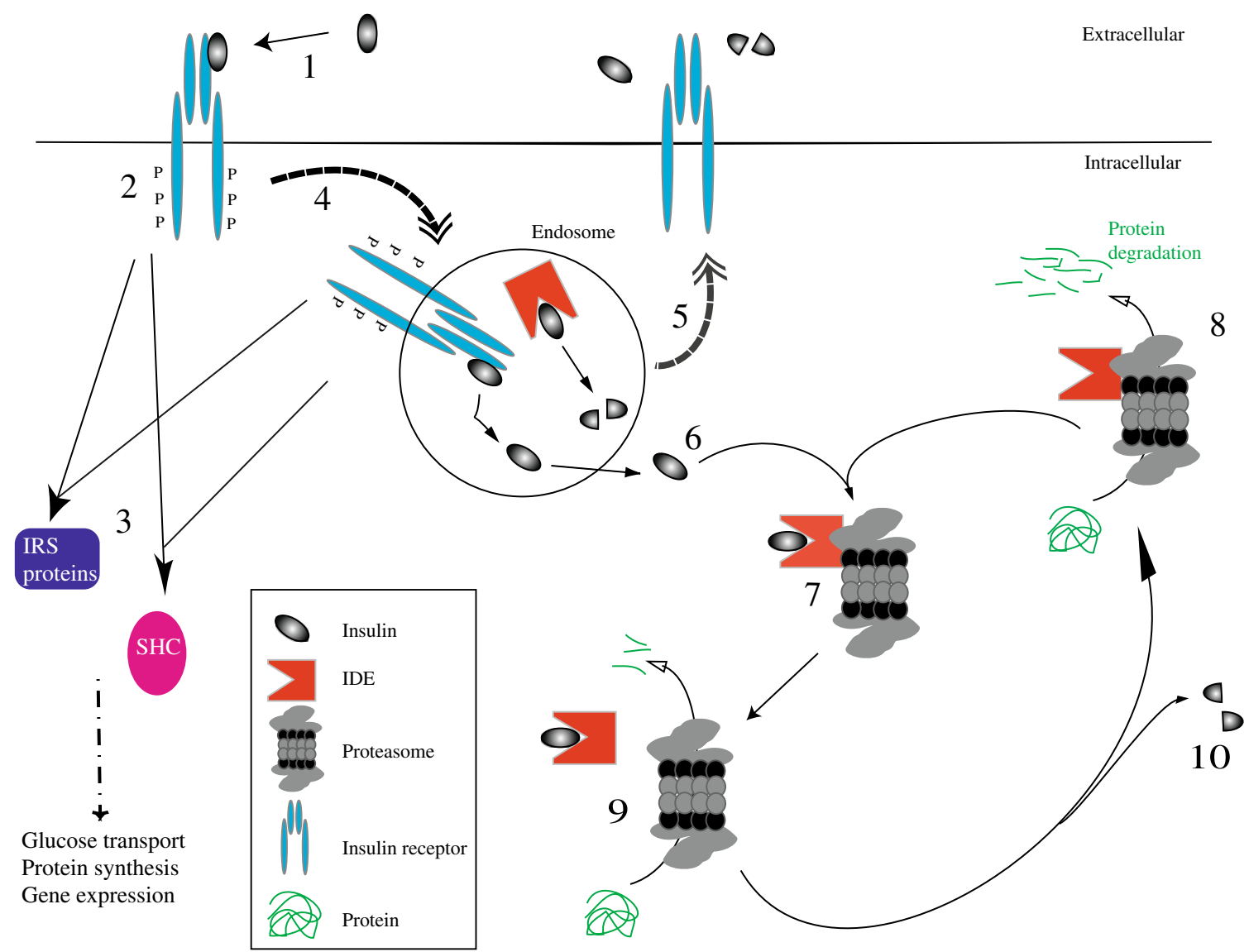

Fig. 1 Schematic diagram of insulin degradation and its interaction with insulin action. This includes how insulin degradation acts to inhibit the proteasome and, hence, protein degradation. Insulin binds to the insulin receptor on the cell surface (1) causing receptor autophosphorylation (P) and activating the receptor tyrosine kinase (2). Other molecules within the cascade are then activated (3), increasing glucose uptake (in muscle and fat), glycogen synthesis and mitogenesis. Following insulin binding, the receptor is internalised into endosomes (4), where degradation begins. Insulin receptor is recycled to the cell surface along with degraded and intact insulin (5). Both intact and degraded insulin also enter the cytosol (6), where insulin binds to cytosolic IDE, some of which is associated with the proteasome (7). IDE increases proteasomal activity (8). Insulin binding to IDE causes dissociation of the IDE-proteasome complex and proteasome activity is decreased (9). Following insulin degradation (10), IDE will reassociate with the proteasome (8). The broken line from step 3 indicates that intervening steps have been omitted. SHC, Src homology 2 domain-containing proteins 
variant are not altered. This correlates with the data on the activity of IDE under normal glucose conditions, but does not agree with the observations under high glucose. Incubation of adipocytes with high insulin concentrations causes insulin to be internalised and processed via a nondegradative pathway [24], and retroendocytosis is increased [25].

One limitation of this study [22] is the use of cell extracts to determine IDE activity. It would be interesting to see what the effect of glucose and insulin concentrations were on whole cell IDE activity (i.e. insulin degradation). If changes in IDE activity are seen in whole cells, the effects on the regulatory actions of IDE should be investigated. This could show that changes in glucose and/or insulin levels alter IDE activity and then alter, for example, proteasome activity, changing total cellular protein degradation. As stated at the beginning of this Commentary, each symptom of diabetes is not seen in isolation - many must interact.

In the clinical situation, alterations in glucose and/or insulin levels would alter the activity of IDE, causing changes in the rate of removal of circulating insulin. Whether the changes reported by Pivovarova et al. [22] are localised to the liver or occur in other insulin-sensitive tissues (e.g. muscle, fat, and kidney) remains to be determined. The investigators did not show an effect of hyperglycaemic and/ or hyperinsulinaemic clamps in humans on the expression of IDE mRNA in subcutaneous fat [22]. This could be due to the relatively short duration of the clamp studies compared with the in vitro experiments or may instead be the result of the investigation of a different cell/tissue type.

Insulin metabolism is an important part of insulin action. Insulin metabolism should be considered very carefully in the clinical situation. Altered metabolism of insulin will cause the action of externally administered insulins (including insulin analogues) to be changed. In some cases, insulin analogues are metabolised differently from native insulin even in the 'normal' state [26].

The cellular response to insulin is controlled by the removal of insulin from the circulation and its degradation. Figure 1 shows a schematic representation of insulin degradation and its interaction with insulin action on both tyrosine kinase cascades and protein degradation. Insulin binds to the insulin receptor on the cell surface, causing receptor autophosphorylation and activating the receptor tyrosine kinase [27]. This activates other molecules within the cascade, starting with IRS proteins and Src homology 2 domain-containing (SHC) proteins [27, 28]. Multiple other proteins are phosphorylated, leading to an increase in glucose uptake (in muscle and fat), glycogen synthesis and mitogenesis. These actions of insulin will be terminated by insulin degradation and subsequent dephosphorylation of the receptor [1]. Following insulin binding, the receptor is internalised into endosomes, where degradation begins [1]. Insulin receptor is recycled to the cell surface along with degraded and intact insulin. Intact and degraded insulin also enter the cytosol, where insulin binds to cytosolic IDE, some of which is associated with the proteasome. The interaction of IDE with the proteasome increases proteasome activity [1]. Binding of insulin to IDE causes the dissociation of the IDE-proteasome complex and, thus, the inhibition of proteasome activity [29]. Following insulin degradation, IDE will reassociate with the proteasome. As shown by Pivovarova et al. [22], when insulin levels are increased (under 'normal' glucose conditions), insulin degradation increases, which will cause the activity of insulin on glucose metabolism and growth to be abrogated. However, the degradative process is also involved in certain actions of insulin, including inhibition of protein degradation [30, 31]. An increase in insulin degradation by an increase in insulin levels, as seen in the study by Pivovarova and colleagues under normal glucose conditions [22], would increase the inhibition of protein degradation. The abolishment of this increased insulin degradation by hyperglycaemia would reduce the inhibition of protein degradation by insulin. This could lead to serious protein wasting if left unchecked. In patients with type 2 diabetes, who tend to have hyperinsulinaemia and hyperglycaemia, the activity of IDE (at least in the liver) will be reduced, pushing insulin levels in the blood even higher.

Acknowledgements W. C. Duckworth is financially supported by the Office of Research and Development, Medical Research Service, US Department of Veterans Affairs. The contents of this manuscript do not represent the views of the Department of Veterans Affairs or the US Government.

Duality of interest The authors declare that there is no duality of interest associated with this manuscript.

\section{References}

1. Duckworth WC, Bennett RG, Hamel FG (1998) Insulin degradation: progress and potential. Endocr Rev 19:608-624

2. Affholter JA, Hsieh C-L, Francke U, Roth RA (1990) Insulindegrading enzyme: stable expression of the human complementary DNA, characterization of its protein product, and chromosomal mapping of the human and mouse genes. Mol Endocrinol 4:1125-1135

3. Hamel FG, Bennett RG, Upward JL, Duckworth WC (2001) Insulin inhibits peroxisomal fatty acid oxidation in isolated rat hepatocytes. Endocrinology 142:2702-2706

4. Leissring MA, Farris W, Wu X et al (2004) Alternative translation initiation generates a novel isoform of insulin-degrading enzyme targeted to mitochondria. Biochem J 383:439-446

5. Hamel FG, Mahoney MJ, Duckworth WC (1991) Degradation of intraendosomal insulin by insulin-degrading enzyme without acidification. Diabetes 40:436-443 
6. Affholter JA, Fried VA, Roth RA (1988) Human insulindegrading enzyme shares structural and functional homologies with E. coli protease III. Science 242:1415-1418

7. Bennett RG, Fawcett J, Kruer MC, Duckworth WC, Hamel FG (2003) Insulin inhibition of the proteasome is dependent on degradation of insulin by insulin-degrading enzyme. J Endocrinol 177:399-405

8. Duckworth WC, Bennett RG, Hamel FG (1998) Insulin acts intracellularly on proteasomes through insulin-degrading enzyme. Biochem Biophys Res Comm 244:390-394

9. Hamel FG, Bennett RG, Duckworth WC (1998) Regulation of multicatalytic enzyme activity by insulin and the insulindegrading enzyme. Endocrinology 139:4061-4066

10. Kupfer SR, Wilson EM, French FS (1994) Androgen and glucocorticoid receptors interact with insulin degrading enzyme. J Biol Chem 269:20622-20628

11. Kayalar C, Wong WT (1989) Metalloendoprotease inhibitors which block the differentiation of L6 myoblasts inhibit insulin degradation by the endogenous insulin-degrading enzyme. J Biol Chem 264:8928-8934

12. Semple JW, Lang Y, Speck ER, Delovitch TL (1992) Processing and presentation of insulin. III. Insulin degrading enzyme: a neutral metalloendoproteinase that is non-homologous to classical endoproteinases mediates the processing of insulin epitopes for helper T cells. Int Immunol 4:1161-1167

13. Adames N, Blundell K, Ashby MN, Boone C (1995) Role of yeast insulin-degrading enzyme homologs in propheromone processing and bud site selection. Science 270:464-467

14. Karamohamed S, Demissie S, Volcjak J et al (2003) Polymorphisms in the insulin-degrading enzyme gene are associated with type 2 diabetes in men from the NHLBI Framingham Heart Study. Diabetes 52:1562-1567

15. Prince JA, Feuk L, Gu HF et al (2003) Genetic variation in a haplotype block spanning IDE influences Alzheimer disease. Hum Mutat 22:363-371

16. Bjork BF, Katzov H, Kehoe P et al (2007) Positive association between risk for late-onset Alzheimer disease and genetic variation in IDE. Neurobiol Aging 28:1374-1380

17. Farris W, Mansourian S, Chang Y et al (2003) Insulin-degrading enzyme regulates the levels of insulin, amyloid $\beta$-protein, and the $\beta$-amyloid precursor protein intracellular domain in vivo. Proc Natl Acad Sci USA 100:4162-4167

18. Farris W, Mansourian S, Leissring MA et al (2004) Partial loss-offunction mutations in insulin-degrading enzyme that induce diabetes also impair degradation of amyloid $\beta$-protein. Am J Pathol 164:1425-1434

19. Hamel FG, Upward JL, Bennett RG (2003) In vitro inhibition of insulin-degrading enzyme by long-chain fatty acids and their coenzyme A thioesters. Endocrinology 144:2404-2408

20. Grasso G, Rizzarelli E, Spoto G (2008) How the binding and degrading capabilities of insulin degrading enzyme are affected by ubiquitin. Biochim Biophys Acta 1784:1122-1126

21. Camberos MC, Perez AA, Udrisar DP, Wanderley MI, Cresto JC (2001) ATP inhibits insulin-degrading enzyme activity. Exp Biol Med 226:334-341

22. Pivovarova O, Gögebakan Ö, Pfeiffer AFH, Rudovich N (2009) Glucose inhibits the insulin-induced activation of the insulindegrading enzyme in HepG2 cells. Diabetologia. doi:10.1007/ s00125-009-1350-7

23. Farris W, Leissring MA, Hemming ML, Chang AY, Selkoe DJ (2005) Alternative splicing of human insulin-degrading enzyme yields a novel isoform with a decreased ability to degrade insulin and amyloid $\beta$-protein. Biochemistry 44:6513-6525

24. Jochen A, Berhanu P (1987) Effects of metalloendoprotease inhibitors on insulin binding, internalization and processing in adipocytes. Biochem Biophys Res Commun 142:205-212

25. Levy J, Olefsky JM (1987) The effect of insulin concentration on retroendocytosis in isolated rat adipocytes. Endocrinol 120:450-456

26. Fawcett J, Tsui BT, Kruer MC, Duckworth WC (2004) Reduced action of insulin glargine on protein and lipid metabolism: possible relationship to cellular hormone metabolism. Metabolism 53:1037-1044

27. White MF (2002) IRS proteins and the common path to diabetes. Am J Physiol Endocrinol Metab 283:E413-E422

28. Sasaoka T, Kobayashi M (2000) The functional significance of Shc in insulin signaling as a substrate of the insulin receptor. Endocr J 47:373-381

29. Bennett RG, Hamel FG, Duckworth WC (1994) Identification and isolation of a cytosolic proteolytic complex containing insulin degrading enzyme and the multicatalytic proteinase. Biochem Biophys Res Commun 202:1047-1053

30. Fawcett J, Permana PA, Levy JL, Duckworth WC (2007) Regulation of protein degradation by insulin-degrading enzyme: analysis by small interfering RNA-mediated gene silencing. Arch Biochem Biophys 468:128-133

31. Fawcett J, Hamel FG, Duckworth WC (2001) Characterization of the inhibition of protein degradation by insulin in L6 cells. Arch Biochem Biophys 385:357-363 